\title{
CATALYTIC OXIDATION OF METHYLENE BLUE
}

\author{
T. Lupaşcu*, M. Ciobanu, V. Boțan, A. Nistor \\ Institute of Chemistry of ASM, 3 Academy str., Chisinau, MD-2028, Republic of Moldova \\ Email: lupascut@gmail.com
}

\begin{abstract}
The intact activated carbon CAN-8, obtained from nutshells by activation with water vapors, in the presence of oxygen and at relatively low temperatures, possesses catalytic activity, caused by the presence of alkaline functional groups on its surface, as well as by the formation, in these experimental conditions, of the $\mathrm{OH}^{*}$ radical, which has a high oxidation potential. After 25 cycles of the process of methylene blue oxidation, the data of chromatographic analyses indicate the presence of three organic components in the solution.
\end{abstract}

Keywords: catalytic oxidation, methylene blue, activated carbon.

\section{Introduction}

Waste waters generated by coloring pans are toxic and non-biodegradable substances. The presence of these substances in surface waters leads to the intoxication of aquatic flora and fauna. Modern technologies of waste waters purification from colorants are known, which comprise procedures of sorption of these toxicants on mineral and/or carbonic adsorbents [1].

The utilization of solid catalysts and first of all, of those on the basis of activated carbons, for the oxidation of organic compounds in aqueous media, represents an original solution of significant promise.

The procedure of waste waters purification from methylene blue in the presence of the catalyst obtained on the basis of manganese oxide nanoparticles and hydrogen peroxide is known [2]. Also, was described the procedure of catalytic oxidation of methylene blue at various temperatures $\left(50^{\circ} \mathrm{C}, 65^{\circ} \mathrm{C}, 80^{\circ} \mathrm{C}\right)$ and oxygen purging, in the presence of activated carbons obtained from olive stones by activation with water vapors and subsequent impregnation with copper(II) oxide [3].

The elimination of organic substances from waste waters, using the method of adsorption on porous adsorbents, is widely used in various technologies.

Oxidative treatment leads to the destruction of organic compounds with the formation of non-toxic products. The choice of alternative technologies depends on the content and stability towards oxidation of organic pollutants. In this sense, hydrogen peroxide is the proper agent for waste waters that contain relatively small quantities of organic pollutants.

Synthesis of new catalysts which would oxidize organic pollutants in waters, in order to obtain non-toxic products at low temperatures represents an important objective for industrial applications.

Although methylene blue has antimicrobial and antifungal actions, it also exhibits a negative influence on plants and therefore it has to be eliminated from waste waters.

\section{Results and discussions}

Samples of $50 \mathrm{mg}$ of activated carbon CAN-8 (the $0,06-0,08 \mathrm{~mm}$ fraction) and volumes of $100 \mathrm{~mL}$ of methylene blue solution $(\mathrm{C}=20 \mathrm{mg} / \mathrm{L})$ were introduced in two reactors with magnetic stirrers and water cloaks. Reactors' content was heated up to $50^{\circ} \mathrm{C}$. Nitrogen was bubbled trough the solution with the adsorbent from the first reactor, and oxygen - in the second reactor, at a pressure of $2 \mathrm{~atm}$. After $\sim 10 \mathrm{~min}$ the quantity of methylene blue drastically reduced. The colorless solution from the second reactor was transferred into a $100 \mathrm{~mL}$ calibrated flask, and demineralized water was added to the mark. A new portion of methylene blue, of the same volume and concentration, was added to the reactor where the activated carbon remained, and the oxidation procedure was repeated for another 10 min. Thus, 25 cycles were performed. The solution through which nitrogen was purged remained colored, i.e. the oxidation process of methylene blue did not occur. Only the adsorption process took place.

It is known that functional alkaline groups on the activated carbon surface possess catalytic activity [3]. The concentration of the functional alkaline and acid groups on the surface of the activated carbon CAN-8 is presented in Table 1. 
Ionic exchange capacity of the activated carbon $\mathrm{CAN}-8$ and the $\mathrm{pH}$ values of the water extract

\begin{tabular}{|c|c|c|c|c|}
\hline Nr. & Type of AC & $\begin{array}{c}\text { Cs / alkaline } \\
\text { mg- equiv/g }\end{array}$ & $\begin{array}{c}\text { Cs / acid } \\
\mathrm{mg} \text {-equiv/g }\end{array}$ & $\mathrm{pH}$ \\
\hline 1 & CAN-8. (nutshells) & 0.555 & 0.139 & 7.0 \\
\hline
\end{tabular}

The data in Table 1 clearly point out the predominance of alkaline groups on the surface of the intact activated carbon CAN-8. peroxide.

It is mentioned in [3] that the formation of alkaline oxides is accompanied by the formation of hydrogen

Table 2 shows the data regarding the structural parameters of the activated carbon CAN-8 (the specific surface $\mathrm{S}_{\mathrm{BET}}$, the surface of mesopores $\mathrm{S}_{\mathrm{Me}}$, the volume of the micropores $\mathrm{W}_{0}$, the characteristic energy $\mathrm{E}_{0}$, the semi-width of crevice-shaped micropores $\mathrm{X}_{0}$ ).

Table 2

Structural parameters of the activated carbon CAN-8.

\begin{tabular}{|c|c|c|c|c|c|c|}
\hline Nr. & Type of AC & $\begin{array}{c}\mathrm{S}_{\mathrm{BET}} \\
\mathrm{m}^{2} / \mathrm{g}\end{array}$ & $\begin{array}{c}\mathrm{S}_{\mathrm{Me}}, \\
\mathrm{m}^{2} / \mathrm{g}\end{array}$ & $\begin{array}{c}\mathrm{W}_{0}, \\
\mathrm{~cm}^{3} / \mathrm{g}\end{array}$ & $\begin{array}{c}\mathrm{E}_{0,} \\
\mathrm{~kJ} / \mathrm{mol}\end{array}$ & $\begin{array}{c}\mathrm{X}_{0,} \\
\mathrm{~nm}\end{array}$ \\
\hline 1 & CAN-8.(nutshells) & 708 & 166 & 0,35 & 22,41 & 0,45 \\
\hline
\end{tabular}

The data shown in Tab. 2 indicate a high value for the surface of the mesopores of the activated carbon CAN-8, which is very important in the case of potential utilization of such an adsorbent in catalytic processes.

Table 3 shows the quality indices of the studied adsorbent, obtained from the adsorption isotherm of methylene blue, iodine and benzene vapors.

Table 3

Indices of quality of the activated carbon CAN-8, obtained from the adsorption isotherm of methylene blue, iodine and benzene vapors.

\begin{tabular}{|c|c|c|c|c|}
\hline \multirow{2}{*}{ Nr. } & Type of AC & \multicolumn{2}{|c|}{ Indices } & Vs (the exicator method) \\
\cline { 3 - 4 } & & $\left.\mathrm{I}_{2} / \mathrm{mg} \mathrm{I}_{2} / \mathrm{g}\right)$ & $\mathrm{AM}(\mathrm{mg} / \mathrm{g})$ & 0,62 \\
\hline 1 & CAN-8.(nutshells) & 1095,6 & 300,33 & 0 \\
\hline
\end{tabular}

The data presented in Tab. 3 show a high adsorption capacity of the investigated activated carbon.

Fig.1. shows the UV/Vis spectrum of the initial methylene blue and of that subjected to catalytic oxidation, in the presence of the intact activated carbon $\mathrm{CAN}-8$ and oxygen at $50^{\circ} \mathrm{C}$.

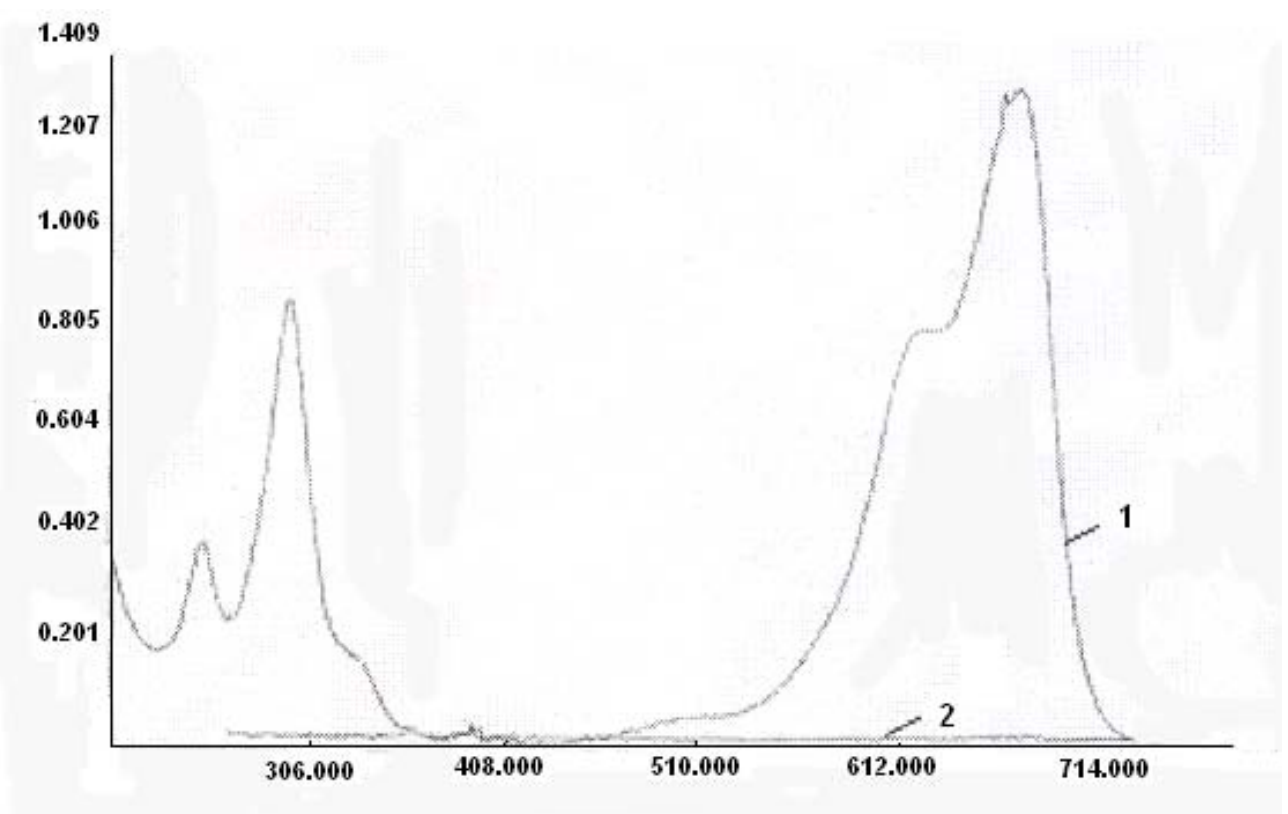

Fig.1. UV/Vis spectrum of methylene blue: (1) initial 20mg/L solution and (2) after the oxidation process. 
Figure 1 points out the result of the complete catalytic oxidation of methylene blue. The band at $290 \mathrm{~cm}^{-1} \mathrm{completely}$ disappeared, as well as all other bands in the visible region. As a result of purging oxygen through the solution containing methylene blue, the intact activated carbon CAN-8, the methylene blue is adsorbed on the surface of the adsorbent, just as the oxygen, which leads to the appearance of a potential jump at the adsorbent-solution frontier. This is due to the oxygen electrode on the surface of the activated carbon, which confers it properties of an oxidation catalyst [4]. As a result, the activated carbon acquires a positive charge and thus, the accumulation of hydrogen peroxide, as an intermediary product, at the contact surface activated carbon-solution, becomes possible [5]:

$$
\begin{aligned}
& \mathrm{O}_{2}(\mathrm{ads})+2 \mathrm{H}_{2} \mathrm{O}+2 \mathrm{e} \rightarrow \mathrm{H}_{2} \mathrm{O}_{2}+2 \mathrm{OH}^{-} \\
& \mathrm{H}_{2} \mathrm{O}_{2} \rightarrow 2 \mathrm{OH}^{-} \\
& 2 \mathrm{OH}^{-}+2 \mathrm{e} \rightarrow 2 \mathrm{OH}^{-}
\end{aligned}
$$

It is well known that hydroxyl radicals $\mathrm{OH}^{\cdot}$ easily attack organic compounds, due to their high reactivity, and transform it into simple compounds which, eventually, may be mineralized to $\mathrm{CO}_{2}, \mathrm{H}_{2} \mathrm{O}$ and mineral species [6]. Generally, due to the fast reaction of the hydroxyl-radical in oxidizing processes, the advanced oxidation technology is characterized by an increased reaction rate and a reduced treatment time.

It is possible that the $\mathrm{OH}^{\cdot}$ radical, along with functional alkaline groups on the surface of the intact activated carbon CAN-8, plays a role in the process of oxidation of methylene blue. In any case, after 25 cycles of methylene blue oxidation, the number (concentration) of alkaline functional groups on the surface of the intact activated carbon CAN-8 decreased from $0.55 \mathrm{mg}$-equiv/g to $0.05 \mathrm{mg}$-equiv/g, and the duration of the oxidation process was $\sim 10 \mathrm{~min}$ for each cycle. Authors mention in [7] the possibility of formation of various forms of adsorbed oxygen during its transformation from mobile forms, obtained in the first stage of the adsorption process, into strictly fixed forms which appear during longer interactions, or somewhat higher temperatures.

It should be mentioned that the $\mathrm{OH}^{\circ}$ radical, having an oxidation potential of $2.8 \mathrm{~V}$, which is higher than the oxidation potential of ozone $(2.07 \mathrm{~V})$, may oxidize sodium dodecylsulfate to $\mathrm{CO}_{2}$ and $\mathrm{H}_{2} \mathrm{O}$ [8] .

Fig. 2 presents the NMR spectrum (400 megacycles) of methylene blue oxidized with intact activated carbon CAN-8 in the presence of oxygen at 2 atmospheres, for 2 hours, at $50^{\circ} \mathrm{C}$. The NMR spectrum of intact methylene blue is shown in Fig. 3.

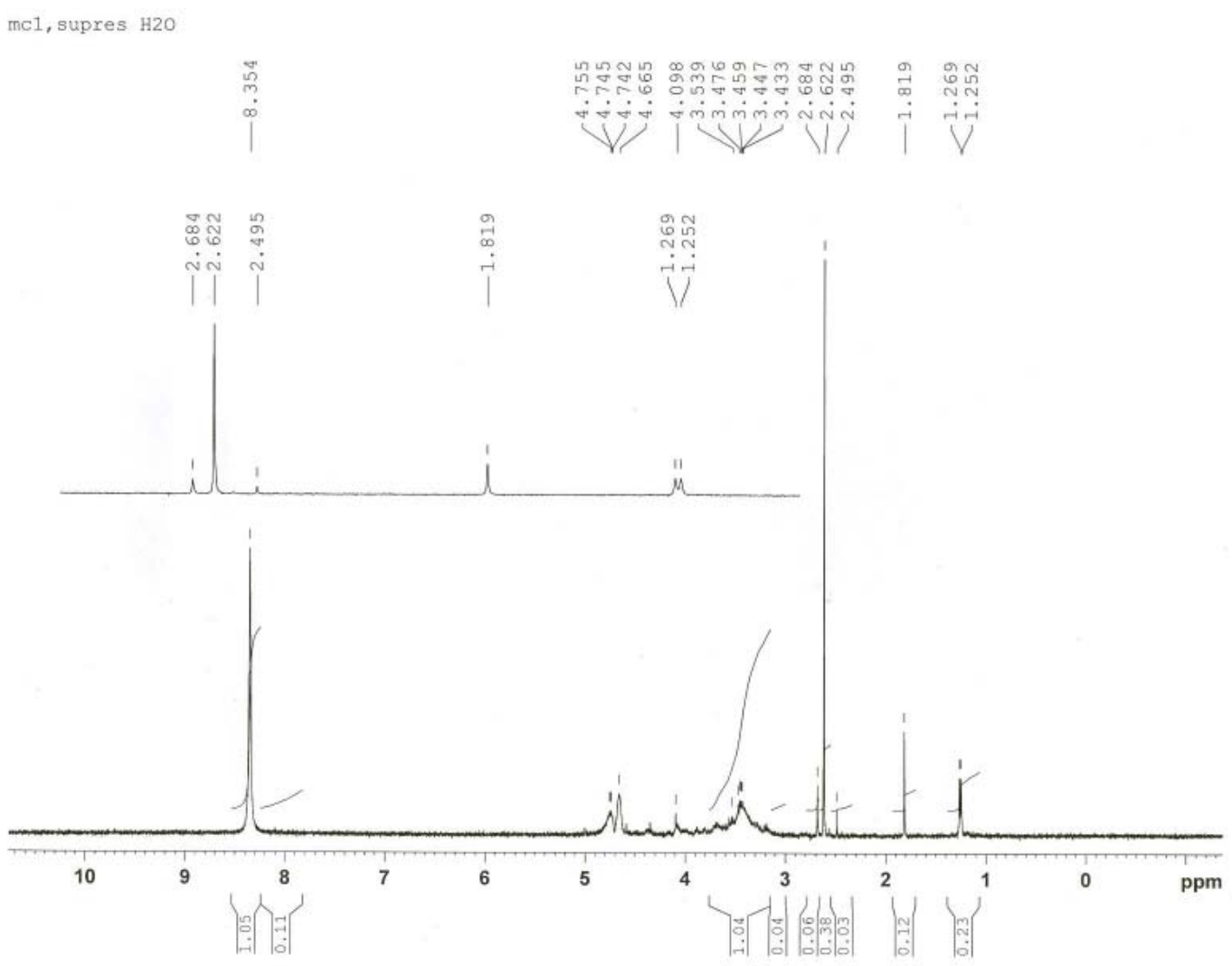

Fig.2. NMR spectrum of oxidation products of methylene blue in the presence of intact activated carbon and oxygen purging (pressure of 2 atmospheres) at $50^{\circ} \mathrm{C}$. 


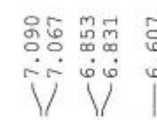

mc2 (colorant), supres H2O

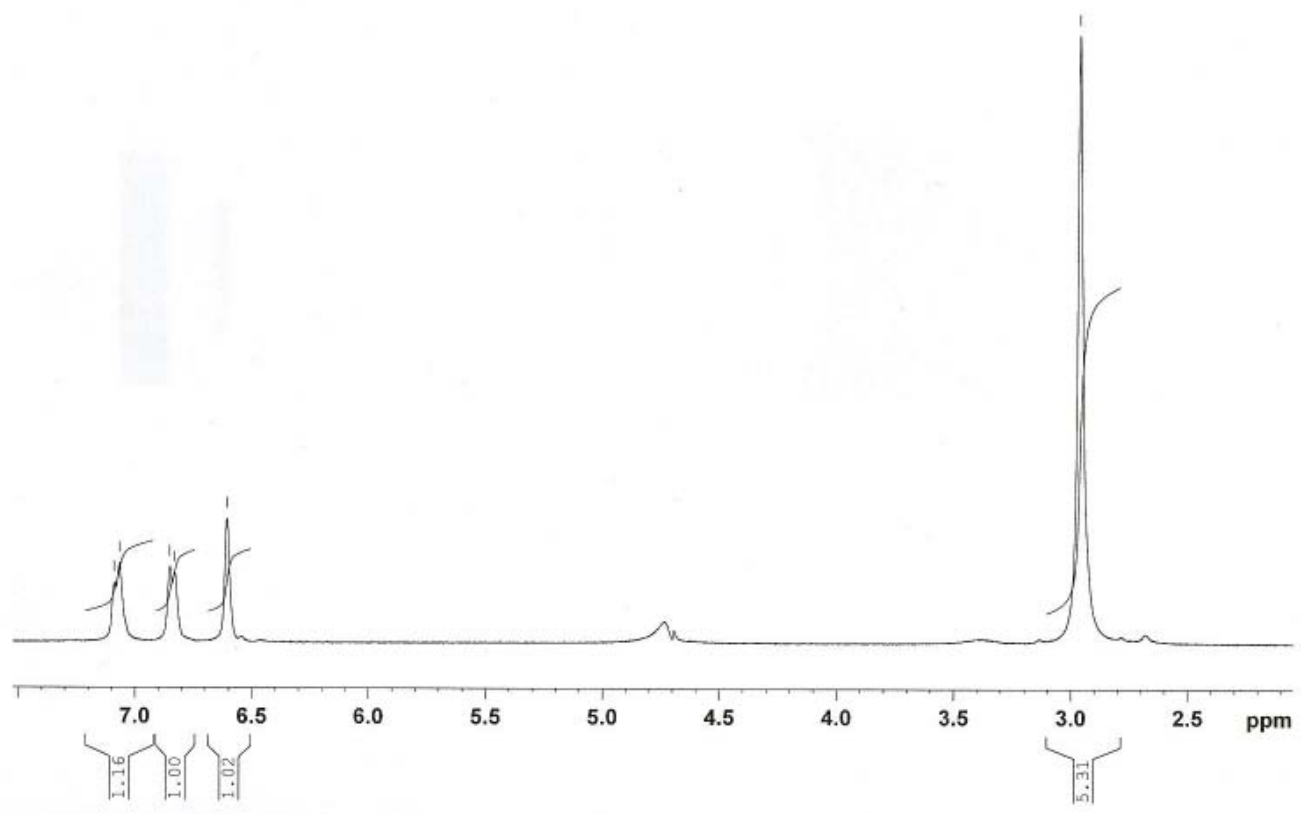

Fig. 3. NMR spectrum of methylene blue.

Figures 2 and 3 clearly indicate that as a result of the catalytic oxidation of methylene blue, the substance undergoes transformations and several organic structures remain in the solution.

\section{Conclusions}

1. The intact activated carbon CAN-8, obtained from nutshells using the physico-chemical method under experimental conditions, possesses catalytic activity, which is due to the presence on the intact activated carbon of functional alkaline groups, as well as to the formation of the $\mathrm{OH}$ radical at the interface, which has a high oxidation potential.

2. Catalytic performance of the intact activated carbon CAN-8 in the process of methylene blue oxidation was displayed during 25 cycles, and it was acknowledged that the content of alkaline groups on the surface of the activated carbon diminished significantly after the last cycle - from $0.55 \mathrm{mg}$-equiv/g to $0.05 \mathrm{mg}$-equiv $/ \mathrm{g}$, without significant decrease of its catalytic activity.

3. As a result of the process of methylene blue oxidation, fragments are obtained from the initially studied organic substance.

\section{References}

[1]. Zhang Weixin Yang. Process for treating waste water of metylene blue dye and process for preparing catalyst. C02F 1/72; B01J 23/34; C01G 45/02; (+5). CN 1792866 (A) - $2006-06-28$.

[2]. H.S.Silva, N.D.Martinez, A.C.Deiana, J.E. Gonzalez. Catalytic oxidation of methylene blue in aqueous solutions. $-2^{\text {nd }}$ Mercosur Congress on Chemical Engineering. 2005. p. 1-8.

[3]. Roop Chand Bansal, Jean-Baptiste Donnet, Fritz Stoeckli. Active Carbon. Marcel Dekker, INC. New York and Basel. 1988. p.107.

[4]. В.В.Стрелко, Н.Т.Картель, Л.А.Клименко, К.А. Каздобин. Электрохимические свойства углеродных гемосорбентов. - ЖПХ, №6, 1987. с.1257-1260.

[5]. А.И.Анурова, В.С. Даниель-Бек, А.Л.Ротинян. - Электрохимия, 1968, т.4, №7, с.815-821.

[6]. Rein Munter. Advanced oxidation processes - current status and prospects - Proc. Estonian Acad.Sci.Chem., 2001, 50, 2, 59-80.

[7]. А.Н.Фрумкин. Адсорбция и окислительные процессы. - Успехи химии. 1949. т.18,вып.1, с. 9 - 21.

[8]. Н.М.Панич, А.Ф.Селиверстов, Б.Г.Ершов. Фотоокислительное разложение додецилсульфата натрия в водных растворов. - Ж.П.Х., 2008, т.81, вып.12. с. 1991-1995. 